\title{
Investigation Procedures in Syariah Criminal Cases: Challenges Faced by Malaysian Syariah Enforcement Officers in Exercise of Their Arrest Power
}

\author{
Ahmad Azam Mohd Shariff \\ Associate Professor, Faculty of Law, Universiti Kebangsaan Malaysia \\ aazam@ukm.edu.my \\ Mazupi Abdul Rahman
}

Senior Assistant Commissioner, Criminal Investigation Division, Polis DiRaja Malaysia

sharifuddinsalleh@yahoo.com

Nazura Abdul Manap

Associate Professor, Faculty of Law, Universiti Kebangsaan Malaysia

nazura@ukm.edu.my

\section{Ramalinggam Rajamanickam}

Lecturer, Faculty of Law, Universiti Kebangsaan Malaysia

rama@ukm.edu.my

Rizal Rahman

Senior Lecturer, Faculty of Law, Universiti Kebangsaan Malaysia

noryn@ukm.edu.my

Norfajri Ismail

Lecturer, Faculty of Law, Universiti Kebangsaan Malaysia

fajri@ukm.edu.my

Doi:10.5901/mjss.2014.v5n23p471

\section{Abstract}

Every society yearns for justice and fundamental liberties. Nevertheless, the present global demand for unqualified freedom and liberties has turned the task of conducting an arrest into a daunting one. First and foremost, an arrest must be carried out in accordance with law. Secondly, an arrest must also conform to principles on human rights and liberties, which is the matter of striking a balance between individual rights and the rights of the society. In this matter, individual rights to move freely without being subjected to unlawful arrest must be balanced up with the rights of the society to be protected from crimes. Such challenges are also faced by the syariah enforcement officers when conducting arrest on suspects in Malaysian syariah criminal cases. Hence, this research analyses the issue of arrest in Malaysian syariah criminal cases by looking at syariah principles and relevant legal provisions. It then identifies problems pertaining to the issue of arrest and suggests some relevant and practical solutions to them. It is also important to note that most of the syariah criminal cases referred to in this research are cases which are still under investigation. As such, all names and references have been camouflaged for secrecy purposes.

Keywords: arrest; suspect; crimes; syariah criminal investigation; syariah criminal procedure

\section{Introduction}

The issues of justice and human rights have always been under close scrutiny and been keenly debated by people from all walks of life. Some cry for eternal justice and as such demand that they be granted unqualified rights and liberties. On the other hand, there are others who crave for personal rights and liberties but are willing at the same time to relinquish 
them for public safety, peace and security in times of need. To them, there are always times when the right of the general public to live in safety, peace and security will have to be prioritised over individual personal rights and liberties. This is actually the sign of maturity as justice in such a situation is viewed in a more realistic way.

Indeed, the above debate on justice and freedom has an effect on how an accused is arrested under Malaysian man-made and syariah criminal investigation procedures. This should be seen from two perspectives. First and foremost, all arrests should be carried out in accordance with law. Then, all arrests should not transgress human rights and liberties principles. It should also be well understood that these rights and liberties could be rescinded in protection of peace and security of the nation and country. Here is a classic example. Even though every citizen is free to move freely without restrictions, this freedom of physical movement could be rescinded temporarily whenever a citizen is suspected of committing a crime. In such a situation, it is wise and necessary to arrest the suspect so as to enable the necessary interrogation and recording of statement to take place. Such arrest is needed to ensure freedom of the society from criminal threat. Such is the example of how individual freedom of physical movement needs to be balanced up with the right of the public to be protected from criminal danger (Azam, Ruzian, 2002; Zuhaili, 2008, Qayyim, 1953; Azam, 2012).

That is why every arrest of suspect should be conducted in accordance with law once the right of public to be protected from crime is taken into consideration. No one should be arrested unnecessarily and without proper reasons under the states' syariah criminal investigation procedures (Zuhaili, 2008; Turkamani, 1999). In the context of syariah criminal investigation procedures, an investigation of seizeable or non-seizeable offence could only be started once a report is lodged. An investigation could also be initiated once reasonable suspicion of a commission of sinful seizeable offence exist (Azam, Mazupi, 2005; Ashraf, 2004; Zuhaili, 2008; Mawardi, 1996). Should a suspect, in the course of investigation, is later on identified and concrete evidence is obtained against him, only then will he be arrested to facilitate investigation (Azam, Mazupi, 2005).

This paper analyses relevant syariah principles and legal provisions on arrest procedures under Syariah Criminal Procedures (Federal Territories) Act 1997. It then identifies problems relating to conduct of arrest on suspect. This paper then suggests possible suggestions relating to these problems.

\section{Syariah Principles and Legal Provisions on Arrest of Suspect under Syariah (Federal Territories) Act 1997}

Criminal Procedures

Syariah principle allows a suspect to be arrested should there is a strong evidence to prove his involvement or commission of a criminal act. This is to allow his statement to be recorded. At the same time the suspect could also be interrogated so as to allow gathering of proof and useful information that could be used to facilitate investigation. Simultaneously, specific legal provisions on arrest could be found under Syariah Criminal Procedure (Federal Territories) Act 1997.

\subsection{Syariah principles on arrest}

Syariah principles on arrest have long been enacted by the ulama. In order for an arrest to be valid and lawful, it must fulfill specific conditions. A suspect under investigation is called mudda'ā 'alaihi. However, once a suspect is charged in court, he will be referred to as al jāni (Zuhaili, 2008; Al Hidayah, 2011).

When a suspect is subsequently identified in an investigation, syariah principle allows him to be arrested when such need arises. An arrest is termed as al qabdhu. An arrest occurs when a suspect is being physically held, restricting his physical movement. An arrest could also signify a situation whereby a suspect physically follows the arresting officer without the involvement of any physical contact (Zuhaili, 2008).

The three conditions of al takliff (responsibility), al qudrah (power) dan al imān (faith) (Audah, 1986; Al Hidayah, 2011) must be fulfilled before a person could conduct an arrest on a suspect. Al taklif signifies a responsibility of the arresting officer to prevent crimes and unjust acts. Al qudrah refers to the power and ability of such person to eliminate crime while al iman refers to the faith of the existence of Allah SWT while conducting the arrest. The difference here is that there was no specific body entrusted with the power to conduct arrests during the time of the Prophet (Ashraf, 2004).

Several of arrest procedures are outlined by syariah principles. These are actually based on syariah legal maxims such as necessity allows the prohibited, necessity has its own limitation, sacrificing the need of an individual in benefit of the need of the public and choosing the smaller inconvenience (Wahbah, 1982).

Generally speaking, an arrest on a suspect should be conducted in the most suitable manner using the least possible force in accordance with existing circumstances. If a suspect does not resist, the arresting officer need not be too aggressive and physical in conducting the arrest. On the other hand, if a suspect resisted the arrest, the officer may 
use physical force sufficient enough to subdue the suspect (Qudamah, 1984). Syariah principle also stresses that if a suspect to be arrested enters a private building or premise belonging to another person, the arresting officer is allowed to break into such building or premise in arresting the suspect. This is based on the maxim of necessity allows the prohibited (Ashraf, 2004).

A suspect's body could be physically examined and searched upon his arrest. A suspect could also be sent to any expert to enable his body to be thoroughly and physically examined. Such process is allowed as a means of discovering or recovering possible evidence and proof from the suspect's physical body (Zuhaili, 2008). A suspect may also be interrogated in obtaining and gathering information which might facilitate investigation. In other words, such interrogation on a suspect is conducted in search of truth on the suspect criminal involvement. During such process, the suspect will also get a chance to deny his involvement (Zuhaili, 2008; Usamah, 2005). Such interrogation is known as al istijwāb or al istijwāb al muttaham (Zuhaili, 2008).

There were some examples of arrests conducted by the companions of the Prophet SAW in his time. For instance, Abu Umayyah once caught a thief and brought him in front of the Prophet. The thief then confessed of his commission of the theft even though the stolen property was not found on him (Barakbah, 1994). In another example, there was once a woman in the time of the Prophet SAW who went out for prayers. She walked past a man who unfortunately raped her. When she screamed, the man ran off. Meanwhile, a group of muslims from Muhajirin who were passing through that area heard the scream. Upon hearing that she was raped, they immediately investigated and arrested the culprit (Daud, 1973). In yet another instance, a woman was once said to have committed theft during the time of the Prophet SAW. She was then arrested and brought in front of the Prophet. Upon investigation in which her guilt was proven through sound proof and evidence, the Prophet ordered her hands to be cut off in punishment (Bukhari, 1989).

\subsection{Syariah legal provisions on arrest}

Once a report is lodged on a commission of a seizable or non-seizable crime, or when there is a reasonable suspicion of a commission of a seizable offence, an investigation commences. (See section 54 and section 57 of Syariah Criminal Procedure (Federal Territories) Act 1997). Whenever a suspect is identified during such investigation, he may have to be arrested for further investigation and questioning. In a seizable offence, a suspect can be arrested without warrant (Section 18 of Syariah Criminal Procedure (Federal Territories) Act 1997). However in a non-seizable offence, a suspect can only be arrested when a warrant of arrest is issued by a lower syariah court judge (Section 32(1) of Syariah Criminal Procedure (Federal Territories) Act 1997) (Azam, Mazupi, 2005).

Section 10 of Syariah Criminal Procedure (Federal Territories) Act 1997 outlines the fact that in arresting a suspect, a syariah enforcement officer must touches the body of the suspect or physically restricts his movement. However an arrest could occur in other ways. For instance, when a suspect expressly submits himself to an investigating officer either orally or through his conduct, he is under an arrest. The arresting officer however should not use excessive force or restriction unnecessarily (Section 14(1) of Syariah Criminal Procedure (Federal Territories) Act 1997) (Norjihan, 2011). In Kes Tangkap 58-2(KJSK) 2009-Mustafa dan Mas, a report was lodged on an unlawful sexual intercourse. Based on the report, syariah enforcement officers conducted an investigation at the banglo of the suspect. Upon knocking on the front door, the said suspect and his partner were found in a state of suspicion. Further investigation was conducted and both suspects were later on brought to the syariah enforcement office at their own accord for further interrogation and also to enable their statements to be recorded. It is clear from the above case that there was indeed an arrest eventhough there were no physical contact or handcuffing involved.

Despite the disallowance of the use of excessive force in arresting a suspect, a syariah enforcement officer may still use an amount of force sufficient enough to subdue and prevent an aggressive and offensive suspect from escaping (Section 10(1)(2)(3)). Section 11 empowers an arresting officer to break into and conduct a search in any premise in his effort of arresting a suspect. Section 15 meanwhile empowers an officer to conduct a body search on an arrested suspect and confiscate anything that is found on his person. Section 16 empowers the arresting officer to confiscate any dangerous weapon found on the body of a suspect. In Kes Tangkap 47-9-113-2006-Meor Shaharudin dan Harlida, both suspects were arrested on the suspicion of committing an indecent act in public. One of the suspects violently hit down the arresting hand of an officer, causing the said officer to use a considerable amount of force in arresting him. All in all, the reason for arresting a suspect, with or without warrant, is to allow him to be detained, interrogated and also to have the suspect's statement recorded (Norjihan, 2011).

Meanwhile, an arrest warrant plays an extremely important role in ensuring suspect's cooperation throughout an investigation. This is especially so in non-seizable cases. From one perspective, an arrest warrant (Section 32(1)) could be applied in case of the suspect's non-compliance with the earlier released bond or letter of demand demanding for his 
presence. Adversely, the arresting officer could also apply for a warrant of arrest straight away without having to wait for the release of such bond or letter of demand. This is so when the situation warrants such necessity (Norjihan, 2011, Zakri, 2010, Shahrom, 2010).

In reality, it has been the norm for syariah enforcement officers to apply for an arrest warrant from a judge straight away whenever there's a report or information on an occurrence of a non-seizable offence. It is argued that the emergent nature of non seizable cases, such as committing public indecent act, necessitates swift and prompt action. Hence an arrest warrant is applied straight away (Norjihan, 2011, Zakri, 2010, Shahrom, 2010). It is to be noted that most arrest warrants applied in such manner are in incomplete form. This is so as the part of the warrant which requires information on the suspect such as his name, address and details of the offence committed are left blank. The information will only be completed once the raid conducted is over and the suspect arrested. Only after the arrested suspect is brought to the syariah enforcement office for questioning and recording of his statement will his name, address and details of offence committed be recorded in the arrest warrant (Norjihan, 2011).

The nature of offences against morality in section 28 and section 29 of Syariah Criminal Offences (Federal Territories) Act 1997 further necessitates such mode of operation. For instance, the offence of committing immoral and indecent act in public under section 29 is definitely non-seizable in nature and thus requires a warrant before an arrest can be made. It is vehemently argued that since such offence requires swiftness and efficiency every time an arrest is about to be conducted, the arrest warrant need to be applied and issued beforehand even though it is still in incomplete form (Norjihan, 2011). The offence of male impersonation of a woman under section 28 further complicates the situation. This is because the said offence originally carries the maximum punishment of one year imprisonment, making it seizable and requiring no warrant should an arrest is to be conducted. However, the said offence's state of seizability and its nonrequirement of an arrest warrant are still indefinite at the time of raid, depending on its stage of commission. For instance, should a suspect is arrested while attempting to commit such crime, the offence could turn into one of non-seizable requiring an arrest warrant when an arrest is to be made. It is therefore argued that since the offence under section 28 is one which requires swift action and its stage of commission and seizability could only be determined just before the actual arrest, the arrest warrant need to be applied and issued beforehand no matter how incomplete its form may be (Norjihan, 2011, Zakri, 2010, Shahrom, 2010).

It is however observed that in recent times, some enforcement and operation units under different religious departments in this country have resorted to a somewhat different modus operandi. This new mode of operation does not require an application and issuance of arrest warrant at the initial stage of the investigation. Once a report is lodged or information is received on an occurrence of a potential non-seizable offence, a group of investigating officers would go to the crime scene to investigate. Once the reported criminal act is confirmed and there is enough evidence and proof available against the suspect, the investigating officer or officers will move in and detain the suspect briefly. The officer or officers will then quickly ask for the suspect's identity card and the suspect's name, identity card number and address will then be recorded. After that, the suspect will be issued a letter of demand demanding for his presence at the syariah enforcement office at the stipulated date and time to further facilitate investigation. It is to be noted here that the said warrant of arrest is only applied at the later stage of the investigation once the suspect does not comply with the said letter of demand. In this case, the arrest warrant is issued to ensure his presence at the syariah enforcement office and also to ensure his cooperation to be interrogated and his statement recorded. Such warrant will also be applied and issued later on to ensure the accused's presence in court for his prosecution once there is enough proof and evidence to prosecute him (Norjihan, 2011, Zakri, 2010, Shahrom, 2010).

Section 22(2) and section 22(3) emphasize that a suspect cannot be detained for more than 24 hours after his arrest. There are 2 scenarios here. The first one involves interrogation of suspect which is completed within 24 hours. The second scenario involves interrogation which could not be completed within 24 hours. Relating to the first scenario whereby investigating officers manage to complete interrogation within 24 hours, two possibilities may materialise. Firstly, should the investigating officer finds lack of evidence against the suspect, the arrested and interrogated suspect need not be charged and prosecuted in court but should be set free at once. Should fresh evidence is later on found during further investigation and such evidence is deemed strong enough to make a case against the suspect, the accused could then be rearrested and charged. This could be seen in cases of syndicated marriage scheme such as Kes Tangkap 14/20/JSY/1997-Rozali Baba. On the other hand, another possibility may also emerge. Should the investigating officer finds evidence against the suspect during investigation and interrogation and such evidence is deemed strong enough, the arrested and interrogated suspect must now be charged and prosecuted in court (Section 22(4)) (Norjihan, 2011).

Meanwhile, the second scenario involving a situation whereby the interrogation could not be completed within 24 hours might also occur. In such a situation, should the investigating officer fails to secure concrete information and evidence against the suspect, the suspect should immediately be released at once even though the interrogation has not 
been completed (Section 22 (1)(2)(3)(4)). The suspect would, in this matter, be released on bail under section 23 in security of his possible presence if required later. The said bail is not in monetary form but in the form of verbal assurance requiring the said suspect to sign a special form containing his assurance of presence at the syariah enforcement office to assist investigation if so required later (Norjihan, 2011, Zakri, 2010, Shahrom, 2010).

Besides the process of interrogation, section 59(1) of Syariah Criminal Procedure (Federal Territories) Act 1997 simultaneously empowers syariah enforcement officers to record verbal statement of a suspect (Section 58 and section 59). Such recording must be carried out without any element of persuasion or promise (Section 61). In seizable offences, the recording of statement may be done without having to apply for an order to investigate or OTI (Section 57(1)). In contrast, any recording of statement in non-seizable cases can only be carried out after an OTI is obtained (Section 55(2)) (Norjihan, 2011; Zaferi, 2010; Jamilah, 2010; Norhasni, 2010).

It is to be observed that there is no provision under the enactment empowering an investigating officer to bring a suspect to hospital for a medical examination during the time when the suspect is under interrogation and his statement is being recorded (Norjihan, 2011; Zaferi, 2010; Jamilah, 2010; Norhasni, 2010). Hence there is no provision which enables any syariah enforcement officer to collect and obtain, during investigation, samples which may potentially become circumstancial evidence or qarinah such as samples of blood, skin or semen (Sections 5-16). On the other hand, the urgent necessity to collect and obtain qarīnah in cases of illicit sexual intercourse, attempting an illegal intercourse, khalwat and sodomy is sorely felt (Norjihan, 2011; Zaferi, 2010; Jamilah, 2010; Norhasni, 2010).

Inspite of the above, there are indeed some syariah enforcement officers who have taken their own initiatives to collect and obtain circumstantial evidence or qarīnah during the course of their investigation based on necessity or maslahah. In the absence of legal provision, such officers make written application to court in obtaining judicial order to send suspects to hospital for medical examination. Such move is vital in obtaining any circumstantial evidence or qarīnah. These investigating officers use section 230 (2) of Syariah Criminal Procedure (Federal Territories) Act 1997 in making the said written application (Norjihan, 2011; Zaferi, 2010; Jamilah, 2010; Norhasni, 2010). In accordance with section 230 , syariah principles will prevail in cases of lacuna under the said enactment. Hence, based on the argument that syariah principles do allow proof of qarinah in all cases including hudud and qisas (Qayyim, 1994), these investigating officers appeal to the court for an order to allow medical examination to be done on accused to collect any possible qarinah evidence even though there is no legal provision under the enactment allowing such procedure (Norjihan, 2011; Zakri, 2010; Shahrom, 2010; Zaferi, 2010; Jamilah, 2010; Norhasni, 2010). Such situation could be witnessed in illegal sexual intercourse cases of Kes Tangkap 42/51/11 (2003)-Mat dan Zakiah, Kes Tangkap Bil.18/2/JSPH/2008-Mohd Rahimi dan Watie and Pendakwa Syarie Sabah v Rosli bin Abdul Japar Kes Jenayah No: S-3/95-7(7) Tahun 2001 (See also Pendakwa Syarie Sabah v Rosli bin Abdul Japar [2007] JH XXIII Bhgn. II 237). In these cases, DNA evidence have been obtained during investigation. These tendered evidence were then accepted by the court as strong qarīnah proving that there were indeed illegal sexual intercourse between the accuseds. On the top of that, the defence counsel has failed to create doubt on the said DNA evidence.

\section{Syariah Criminal Procedures (Federal Territories) Act 1997: Problems Pertaining to Arrest Procedures}

This is a pure legal research and as such is purely qualitative in nature. It adheres to specific research methodologies in data collection and analysis of problem statements and findings. It first of all adopts an empirical approach. All the materials collected are then analysed by way of content analysis when all related legal provisions and cases are analysed. Critical analysis has also been conducted on all materials on syariah criminal procedures relating to arrest. At the same time, a comparative approach is also used when Malaysian syariah legal provisions on arrest are compared with syariah traditional arrest procedures. Comparison is also done between the syariah arrest procedures and the arrest procedures under the Malaysian Criminal Procedure Code.

As such, two main problems pertaining to arrest procedures of suspect have been identified. The first problem relates to issuance and enforcement of arrest warrant. The second problem relates to the non-existence of legal provision on application and issuance of order for medical examination on suspects.

\subsection{Problems relating to issuance and enforcement of arrest warrant}

It is found that there are some problems pertaining to issuance and enforcement of arrest warrant in non-seizable cases. Arrest warrants are normally applied at an early stage when information on crime is received and a report is lodged. A syariah enforcement officer will, in this case, apply to a judge for a warrant of arrest right before an investigation commences. It is however noted that the arrest warrant is issued in an incomplete form. This is because basic information 
on suspect's identity and details on crime have not been obtained at such an early stage and therefore could not be recorded initially in the warrant. Such practice is flawed, illegal and could nullify the validity of the warrant. Consequentially, this would lead to an illegal arrest, one which could be legally challenged in court (Norjihan, 2011 Shahrom, 2010; Zaferi, 2010; Norhasni, 2010).

In justification, syariah enforcement officers have argued that the emergent nature of non-seizable cases such as male impersonation of a female and public indecency require swift and prompt action. Such cases require an efficient modus operandi as any delay in action would probably leads to suspect escape and failure in operation. Hence, early application and issuance of arrest warrant before the actual investigation commences could increase the success rate of any raid and investigation significantly (Norjihan, 2011; Zakri, 2010; Shahrom, 2010; Zaferi, 2010; Jamilah, 2010; Norhasni, 2010).

Syariah enforcement officers give an example of how a delay in warrant application could derail the success of a raid or an arrest. A specific scenario whereby an officer receives information or report on an occurrence of a non-seizable case is given. The investigating officer has to snoop around and spy on the suspect in verifying identity and type of offence committed each time. It is only after such spying and verification will the officer apply for an arrest warrant from a judge. It is therefore argued that such mode of operation would definitely delay and derail the whole enforcement operation which would eventually allow any suspect to escape (Norjihan, 2011; Zakri, 2010; Shahrom, 2010; Zaferi, 2010; Jamilah, 2010; Norhasni, 2010).

There is an additional justification given by some enforcement officers for allowing such early application and issuance of search warrant even if it means that all information and detail on the suspect are not initially recorded at that stage. They claim that section 55(2) of the enactment requires an investigation officer to apply for an order to investigate or OTI from the Head of Syariah Prosecution first before starting on any investigation process. They further claim that since the OTI need to be obtained beforehand, then an arrest warrant too must be obtained beforehand prior to commencement of any investigation. Such modus operandi is definitely to ensure promptness, swiftness and efficiency in action (Norjihan, 2011; Zakri, 2010; Shahrom, 2010; Zaferi, 2010; Jamilah, 2010; Norhasni, 2010).

They also justify that in such mode of operation, it is impossible for the investigating officer to verify all details pertaining to the suspect and his commission of crime at the beginning of the enforcement operation. This information could only be obtained once the suspect is arrested and interrogated and when his statement is recorded (Norjihan, 2011; Zakri, 2010; Shahrom, 2010; Zaferi, 2010; Jamilah, 2010; Norhasni, 2010).

\subsection{Non-existence of legal provision on application and isuance of order for medical examination on suspects}

It is also noted that there is no legal provision under Syariah Criminal Procedure (Federal Territories) Act 1997 empowering a syariah enforcement officer to make an application to court for an order of sending a suspect to hospital for medical examination. There is also no legal provision under the enactment which empowers the court to grant such order.

In reality, cases such as illicit sexual intercourse, attempting to commit illegal intercourse as well as sodomy requires such procedure. In addition, suspects of such cases must be sent for medical examination as soon as possible as this would allow related and unadultered samples to be taken as evidence of qarinah at the earliest possibility (Norjihan, 2011; Zakri, 2010; Shahrom, 2010; Zaferi, 2010; Jamilah, 2010; Norhasni, 2010). First of all, the doctor will firstly collect swaps of samples from the suspect. These collected samples will then be put in a sealed and labeled container to avoid any tampering of proof. Based on his expertise and professional findings on the suspect's physical body and the samples, the examining doctor will then write a medical report. These samples will next be sent to the chemist at the chemist department. Upon receiving these samples, the chemist will then open the seal of each container and conduct related tests on the samples. After completion of each test, he will resealed respective containers and put new labels on each one of them as proof of specific tests conducted on all samples. Last but not least, the chemist himself will write his own report containing his findings based on all conducted tests. It is to be observed that any effort of tendering qarinah evidence involves adducing expert evidence from medical doctor and chemist (Sections 33-34 Syariah Evidence (Federal Territories) Act 1997) as well as documentary evidence of written reports from the experts (Sections 48-56 Syariah Evidence (Federal Territories) Act 1997).

Hence there is no doubt that these qarinah evidence will serve as corroborative evidence to the other evidence collected by the investigating officer during the course of investigation (See also section 230 (2) Syariah Criminal Procedure (Federal Territories) Act 1997) (Qayyim, 1994). Such situation is seen in cases of illicit sexual intercourse of Kes Tangkap 42/51/11 (2003)-Mat dan Zakiah, Kes Tangkap Bil.18/2/JSPH/2008-Mohd Rahimi dan Watie dan Pendakwa Syarie Sabah v Rosli bin Abdul Japar Kes Jenayah No: S-3/95-7(7) Tahun 2001 (See also Pendakwa Syarie Sabah v Rosli bin Abdul Japar [2007] JH XXIII Bhgn. II 237). 
As we have emphasized before, there is no legal provision under the enactment to empower a syariah enforcement officer to make an application to court for an order to send a suspect to hospital for medical examination. There is simultaneously no legal provision to empower the court to grant such order. We have also realised how such provisions are needed to enable qarinah evidence to be collected during investigation in enabling such evidence to be tendered and adduced later on during prosecution (Norjihan, 2011; Zakri, 2010; Shahrom, 2010; Zaferi, 2010; Jamilah, 2010; Norhasni, 2010). Meanwhile there are syariah principles which allow suspects to be phisically examined by experts. However, these principles are not refined and inconclusive (Zuhaili, 2008). At the same time, the existence of Arahan Tetap Pengarah Jabatan Agama Islam Negeri 2007 (Garis Panduan Penguatkuasaan Undang-Undang Jenayah Syariah) from JAKIM and Arahan Ketua Penguatkuasa Agama under each state do not serve as any solution to this problem. This is because these standard operating procedures do not cover anything on issues of application and issuance of order for medical examination on suspects.

\section{Problems Relating to Arrest of Suspect: Suggested Solutions}

Several practical solutions could be offered in solving both problems relating to arrest. These solutions are discussed below.

\subsection{Solution to problem of issuance and enforcement of arrest warrant}

There is a practical solution to the problem relating to issuance and enforcement of arrest warrant. The authors would like to suggest that arrest warrant should not be applied before the conduct of any raid and arrest.

An illustration is hereby given. Each time when an information on a seizable or non-seizable crime is received, the syariah enforcement officer may proceed to spy on the suspect to gather more information. Should the suspect is found to have committed, or in the middle of committing a crime, the enforcement officer may proceed with his raid. Due to the fact that a warrant of arrest has not been applied and issued at that particular point of time, the investigating officer should use section 19 (1) to detain the suspect briefly. During this brief procedure, the name of the suspect, his identity card number as well as his valid address could be obtained.

There are two options that could be used at this juncture. The first option would be for the investigating officer to issue a letter of demand requesting for the presence of the suspect at the syariah enforcement office later on for interrogation and recording of statement. After the issuance of the letter of demand, the suspect would be released immediately. In this case, an arrest warrant will only be applied and issued against the suspect thereafter if the suspect refuses to comply with the said letter of demand. On the other hand, the second option is also available. In the second instance, the investigating officer, after recording the name of the suspect, his identity card number as well as his valid address, would release the suspect without issuing him any letter of demand. In such a situation, with or without conducting further investigation, an arrest warrant could later on be applied and issued against the suspect for interrogation and recording of statement.

In the above two situations, the suspect could thereafter be charged in court within 24 hours of his brief detention should the investigating officer gathers enough evidence and proof against him. Alternatively, in case of lack of evidence to prove his commission of crime, the suspect should be released as illustrated above and arrest warrant is only applied and issued later on in security of his attendance for interrogation and recording of statement. After such interrogation, should the suspect is to be released for the second time due to lack of proof, a second arrest warrant could later on be applied and issued against the suspect for the purpose of charging and producing him in court. This is so when other evidence surfaces, one which is deemed strong enough to implicate him.

In both given suggestions, an investigating officer is still able to react swiftly, efficiently and in accordance with law without having to apply for an arrest warrant at the early stage of investigation. Under section 19 (1), a suspect is only detained briefly and temporarily at the crime scene for the purpose of obtaining his name, identity card number and valid address. There is also no element of injustice as the suspect will be released immediately once all relevant information have been recorded.

Information on the name, identity card number as well as valid address of the suspect obtained during the brief detention could later on be used by the investigating officer to make a valid application to the judge for an arrest warant if needed. In this instance, a valid arrest warrant will be issued in accordance with law. Once a valid warrant of arrest is issued, the suspect will be arrested legally and in accordance with law. Ultimately, the arrest, interrogation and information obtained during interrogation will be legal, valid and unchallengable (Rajakopal, 2008).

It is heartwarming and encouraging to note that some states have improvised and adopted a new modus operandi 
very much similar to the one suggested above, mostly in offences against morality cases. However, in cases of public indecency and male impersonation of a female which are of non-seizable in nature which require warrant of arrest, the procedural application of this new modus operandi needs some improvement and fine-tuning. For instance, the enforcement officers detaining a suspect will ask for the suspect's identity card. The suspect's name, identity card number and address will then be recorded. The suspect will then be issued a letter of demand demanding for his presence at the syariah enforcement office at the stipulated date and time to further facilitate investigation.

This newly implemented mode of operation should be scrutinized carefully. First of all, there are instances whereby the syariah enforcement officers somewhat 'interrogate' the suspect during the process of recording his name, identity card number and address. This practice complicates and lengthens the process and consequentially, could threaten the validity of the said procedure, rendering the validity of the letter of demand meaningless. This is so as such complicated and lengthy procedure may become a harassment to the suspect and thus challengeable on human rights basis. Likewise, it could also result in physical restrain, thus making such procedure illegal and challengeable on the grounds of unlawful arrest or detention. Not to mention that any practice of taking the suspect to the syariah enforcement office for questioning and interrogation, however brief, after issuance of a letter of demand should be immediately stopped. Again, it is argued that such procedure would definitely lead to physical restrain and ultimately challengeable on the basis of unlawful arrest or detention. It must be understood here that any issuance of letter of demand requires an unabetted voluntary act on the part of the suspect to go to the syariah enforcement office for any interrogation and recording of statement. Hence if the suspect voluntariness is compromised, the whole scenario would easily become an unlawful detention or arrest.

\subsection{Solution regarding the non-existence of legal provision on application and issuance of order for medical examination on suspects}

Regarding the second problem, the authors suggest that new provisions should be inserted in the states' syariah criminal procedure enactments. These new legal provisions should legalise the process of sending an arrested suspect to hospital for medical examination. To be exact, there should be a new provision which allows an investigating officer to apply to the court for the suspect to be sent to hospital for medical examination by a doctor. Another new provision should be introduced to empower the court to approve such application should the application made is legally justified.

Indeed such new provisions are not against syariah principles. For instance syariah principle allows a suspect to be physically examined. Another principle allows a suspect to be sent to an expert for further physical examination so as to enable a more detailed and thorough physical and medical examinations performed on the said suspect. This process is aimed at obtaining possible valuable proof and evidence (Zuhaili, 2008). Medical evidence such as samples of blood, semen, hair, pubic hair and hymen tear could all be found and obtained from such medical examination and could be potentially used as corroborative qarinah evidence which may further strengthen the prosecution's case. (See the cases of Pendakwa Syarie Sabah v Rosli bin Abdul Japar Kes Jenayah No: S-3/95-7(7) Tahun 2001 and Pendakwa Syarie Sabah v Rosli bin Abdul Japar [2007] JH XXIII Bhgn. II 237).(Norjihan, 2011).

\section{Conclusion}

In conclusion, individual freedom of physical movement should be balanced up with the rights of the society for crime protection. In ensuring that such balance is maintained, it is also important to ensure that every arrest of suspect should be done legally and in accordance with law and that it should also conform to human rights principles. Hence, the two above-mentioned problems on arrest should be solved wisely and efficiently. This is to ensure relevancy and sustainability of syariah criminal procedures in keeping abreast with current demand.

\section{References}

Adnan Khalid al Turkamani. (1999). Al ljra'at, al Jinaiyyah al Islamiyyah, wa Tatbiquha fi al Mamlakah al Rrabiyyah al Saudiyyah. Riyadh: Markaz li al Dirasat wa al Buhuth fi Akadimiyyah.

Ahmad Azam Mohd Shariff and Ruzian Markom. (2002). Hak Asasi Manusia: Imbangan Antara Hak Ramai dan Hak Individu Dalam Konteks Kebebasan Bersuara di bawah Perlembagaan Persekutuan Malaysia. TTB. Bangi: Fakulti Undang-Undang UKM.

Abdul Qader Audah. (1986). Al Ahkam al Jina'ie al Islami. Beirut: Muassasah al Risalah.

Ashraf Md. Hashim. (2004). The Rights of Suspect and Accused under Islamic and Malaysian Laws. Kuala Lumpur: ILBS.

Ahmad Azam Mohd Shariff. (2012). Prosedur Siasatan dan Pendakwaan Jenayah Syariah: Lakuna dalam Peruntukan Undang-Undang Jenayah Syariah di Malaysia. Doctorate in Law Thesis. Bangi: Universiti Kebangsaan Malaysia. 
Abu Daud. (1973). Sunan Abi Daud. Vol 4. Himms: Darul Hadis.

Al Hidayah. (2011). Terjemahan Al Quran Al Karim Rasm Uthmani Dalam Bahasa Melayu. Selangor: Al Hidayah House of Quran Sdn Bhd.

Al Bukhari. (1989). Sahih Al Bukhari. Vol 5. Al Asqalani, Fath Al Bari. Beirut: Darul Kutb Al Ilmiyyah.

Al Mawardi. (1996). Al Ahkam Al Sultaniyyah. Dr. Asadullah (Trans). London: Ta-Ha Publishers Ltd.

Ahmad 'Azam Mohd Shariff and Mazupi Abdul Rahman. (2005). Siasatan Kes Jenayah Syariah di bawah Akta Prosedur Jenayah Syariah (Wilayah-Wilayah Persekutuan) 1997. Bangi: JUUM UKM

Ibn Qayyim. (1953). Turuq al Hukmiyyah fi al Siasah al Syariyyah. Mesir: Al Sanah al Muhammadiyyah.

Ibn Qayyim. (1994). I'lam al Muwaqqi'ien. Vol 3. Beirut: Darul Kutub IImiyyah.

Ibn Qudamah. (1984). Al Mughni. Vol. 10. Beirut: Darul Fikr.

Jamilah bt Othman. 2010. Prosedur Siasatan Kes Jenayah Syariah. Pegawai Penguatkuasa Agama. Kedah: JAIK.

Mohd Zakri b. Darus. (2010). Prosedur Siasatan Kes Jenayah Syariah. Ketua Unit Siasatan, Bahagian Penguatkuasaan. Melaka: JAIM. Muhammad al Zuhaili. (2008). Al ljra'at al Jinaiyyah al Syariyyah. Jamiah al Syariqah, al Syariqah, Imarat al Arabiyyah al Mutahaddidah.

Norhasni Yusnaida bt. Nor Hashim. (2010). Prosedur Siasatan Kes Jenayah Syariah. Penolong Pegawai Hal Ehwal Islam. Melaka: JAIM.

Rajakopal a/l Arumugam. (2008). Prosedur Siasatan dan Pendakwaan Kes Jenayah Sivil. Pegawai Turus dan Undang-Undang, Jabatan Siasatan Jenayah, Ibupejabat Polis Kontinjen. Kuala Lumpur: Polis Di Raja Malaysia.

Siti Norjihan bt. Saleh @ Md. Ghazali. (2011). Prosedur Siasatan Kes Jenayah Syariah. Penolong Pengarah Siasatan, Cawangan Siasatan. Kuala Lumpur: JAWI.

Syed Agil Barakbah. (1994). Pendekatan Perbandingan Dalam Undang-Undang Prosedur Jenayah. Kertas Kerja Seminar UndangUndang Keterangan dan Prosedur di Mahkamah. Kuala Lumpur: IKIM.

Shahrom bin Maarof. (2010). Prosedur Siasatan Kes Jenayah Syariah. Penolong Pengarah Perancang Operasi, Cawangan Operasi. Selangor: JAIS.

Usamah Ali. (2005). Usul al Muhakamat al Syar'iyyah al Jazaiyyah. Amman Jordan: Dar al Nafais.

Wahbah al Zuhaili. (1982). Nazariyyah al Dharurah. Beirut: Muasssasah al Risalah.

Zaferi bin Zainol Abidin. (2010). Prosedur Siasatan Kes Jenayah Syariah. Pegawai Penguatkuasa Agama. Kedah: JAIK. 